\title{
Comparison of Membrane Filters as a Tool for Isolating Pythiaceous Species from Irrigation Water
}

\author{
Chuanxue Hong, Patricia A. Richardson, and Ping Kong
}

Department of Plant Pathology, Physiology, and Weed Science, Virginia Polytechnic Institute and State University, Hampton Roads Agricultural Research and Extension Center, Virginia Beach 23455. Accepted for publication 15 February 2002.

\begin{abstract}
Hong, C., Richardson, P. A., and Kong, P. 2002. Comparison of membrane filters as a tool for isolating pythiaceous species from irrigation water. Phytopathology 92:610-616.

Filter-based isolation is the primary approach for quantifying plant pathogens in irrigation water; however, the performance of various membranes is largely unknown. This study evaluated nine hydrophilic membranes for recovery of pythiaceous species, a group of very common and destructive pathogens on numerous ornamental plants and many agronomic crops. Three sources of water samples and three plating methods were used for the membrane comparison. Durapore5, Millipore5, and Osmonics 5 filtered $100 \mathrm{ml}$ of irrigation water or $50 \mathrm{ml}$ of irrigation runoff in $10 \mathrm{~s}$ or less, whereas the other membranes required $34 \mathrm{~s}$ to $13.5 \mathrm{~min}$
\end{abstract}

ABSTRACT or even a second membrane to filter the same water sample volume. Millipore5 and Durapore5 showed greater recovery rates than other membranes for all water sources when the membranes were directly inverted onto agar plates. Durapore 5 was also one of the top two membranes for spore suspension and irrigation water samples when membrane washings were spread over the agar surface. Durapore5 was the only membrane that consistently performed well for both spore suspension and irrigation water samples. These data suggest that use of Durapore5 not only increases the sensitivity of filter-based isolation for quantifying pythiaceous species in irrigation water but also saves filtering time.

Additional keywords: integrated pest management, pathogen detection, Phytophthora, Pythium.
Capturing and recycling irrigation runoff is becoming a common practice in the nursery industry, as well as many other crop production businesses, in the wake of global water scarcity (3). Current water recycling methods, however, may return some economically important plant pathogens to irrigation reservoirs where they are then spread back onto crops. Pathogens of economic significance isolated from irrigation water include bacteria $(28,33)$, fungi $(6,29)$, nematodes $(9)$, and oomycetes $(5,11,22$, $26,29,31,34,40)$.

Among these pathogens, pythiaceous species are very common and destructive in nursery production. At least seven species of Phytophthora were recovered from nursery effluents in California (18), and five species were isolated from both nursery irrigation water and runoff in Oklahoma (38). In addition, Pythium spp. were recovered at substantially higher rates compared with Phytophthora spp. from nursery effluents (18).

Recycled water can serve as a principal source as well as an efficient dissemination vehicle of inoculum, which can lead to disease epidemics in nursery crops $(22,24,27,31,36)$. However, the need for quality irrigation water outweighs the potential of increased disease pressure in most situations. Thus, there is an urgent need for effective technologies to monitor recycled water to control major waterborne plant pathogens.

Current approaches for isolating pythiaceous species from irrigation water include bait- and filter-based isolations. A variety of plant species and tissues $(8,15,21,23)$ as well as agar and paper (24) are used as baits. Bait-based isolation is characterized by its sensitivity, although this method offers only qualitative data. Enzyme-linked immunosorbent assay (ELISA) is an additional diagnostic tool for irrigation water $(2,39,41)$. However, many

Corresponding author: C. Hong; E-mail address: chhong2@vt.edu

Publication no. P-2002-0328-01R

(C) 2002 The American Phytopathological Society problems must be resolved before ELISA can be used effectively and interpreted by growers (19). One of the critical problems is false positive diagnosis due to cross-reaction between species and genera of Phytophthora and Pythium. This is unacceptable for processing nursery irrigation water in which Pythium is about 10 to 100 times more numerous in population than Phytophthora and the pathogenicity of the former has not been determined. DNAbased techniques have been developed for identification of several pythiaceous species in pure culture and detection in plant tissues $(7,8,12,14,16,17,32)$, although none has been documented for detection of pythiaceous species in recycled irrigation water.

Filter-based isolation offers quantitative or semiquantitative capability, which enables calculations of disease threshold levels for crops under different environmental conditions and the implementation of different disease control measures (39). This method consists of three major steps: (i) filter a known volume of water sample through a membrane, (ii) culture the propagules retained on the membrane by making a water suspension from washing the membrane in a smaller volume of water agar, or inverting the membrane onto the surface of a selective medium in petri dishes, and (iii) count the developing colonies in the dishes after a 1- to 4-days incubation. Filter-based isolation usually measures pathogen propagules in colony-forming units (CFU) per liter of water and has been widely used in research on pathogen characterization and diagnoses for pythiaceous species in irrigation water.

Filtration has been used to quantify Phytophthora spp. and other potential plant pathogens from water recycling systems in citrus orchards $(1,15,34)$, nurseries $(18,20,38)$, cranberry (23), vegetable $(22,29)$, and tobacco fields (5), as well as from river water (37). A variety of membranes and plating methods were employed in these previous investigations. For example, MacDonald et al. (18) used a $0.45-\mu \mathrm{m}$ Millipore membrane from which the membrane washings were spread onto agar plates. They recovered Phytophthora spp. at 0 to $400 \mathrm{CFU} /$ liter and Pythium spp. at 500 to $1,500 \mathrm{CFU} /$ liter from nursery effluents. von Broembsen and 
Wilson (38) used a 3- $\mu$ m polycarbonate nucleopore membrane that was directly inverted onto agar plates. They isolated Phytophthora spp. at 800 to $900 \mathrm{CFU} /$ liter from irrigation runoff and 1 to 2 CFU/liter from irrigation water. These pioneering investigations provided useful data for developing integrated disease management strategies. However, the same numbers of CFU reported in these previous investigations may not indicate the same levels of pathogen propagules in water when different membranes and plating methods are used.

Sensitivity of filter-based isolation remains a serious concern in monitoring pythiaceous pathogens in irrigation water. For example, Pythium aphanidermatum (Edson) Fitzp. was spread from inoculated plants to noninoculated plants through irrigation water in an ebb-and-flow subirrigation system, but the pathogen in the water was undetectable using filter-based isolation (27). Current filter-based isolation protocols are in imminent need of sensitivity improvement to ensure successful implementation of disease management programs. This is especially evident from the establishment of threshold levels of Phytophthora nicotianae Breda de Haan for the development of foliar blight on Catharanthus roseus under greenhouse conditions (13). The objective of this study was to evaluate levels of detection of various membranes using three sources of water samples and three plating methods.

\section{MATERIALS AND METHODS}

Membranes and filtration. The membranes evaluated in this study are listed in Table 1 and represent different pore sizes and materials. The membranes were purchased from Millipore Corporation (Bedford, MA), Whatman, Inc. (Clifton, NJ), and Osmonics Laboratory Products (Minnetonka, MN). All membranes were $47 \mathrm{~mm}$ in diameter. Filtration was performed with polyphenylsulfone magnetic filter funnels (Gelman Laboratories, Ann Arbor, MI) at $17 \mathrm{psi}\left(43 \mathrm{Hg} / \mathrm{cm}^{2}\right)$ provided by a Welch vacuum pump (Thomas Industries, Inc., Skokie, IL). Membranes and funnels were autoclaved before use.

Membrane comparisons were performed using three sources of water samples and three plating methods (Table 2). Water samples used included spore suspension, nursery irrigation water, and irrigation runoff water. Zoospore suspensions of Phytophthora nicotianae were prepared by incubating mycelial plugs in $1 \%$ sterile soil water extract at $25^{\circ} \mathrm{C}$ under fluorescent light for 3 to $4 \mathrm{~h}$, filtering through cheesecloth, and adjusting to 30 spores per $\mathrm{ml}$. Irrigation water and irrigation runoff samples were collected from a commercial nursery in eastern Virginia on several occasions. This nursery produced container-grown shrubs such as barberries and hollies that are susceptible to diseases caused by pythiaceous species. Plastic containers were sterilized with $4 \%$ bleach (sodium hypochlorite) overnight and rinsed at least three times with the respective water before water samples were taken. Irrigation water samples were taken directly from a sprinkler after the irrigation system ran for $10 \mathrm{~min}$ to clear standing water in the pipe. Irrigation runoff was collected at a point entering a pond used as an irrigation reservoir. Water samples were transported to the laboratory in an ice chest and processed the same day. Irrigation water was supplemented with 30 zoospores per $\mathrm{ml}$ of Phytophthora nicotianae before being filtered to allow an adequate number of colonies to develop in individual petri dishes. Membrane comparisons with different water sample sources were conducted independently. Following filtration of a water sample, isolation proceeded with one (or two) of the three plating methods as shown in Figure 1.

Nine different membranes with three to six replicates each were included in individual comparison tests. Each test was repeated two to three times from different samplings. The sequential order of various membranes filtering a water sample in each test was determined following a randomized complete block design. Individual membranes filtered a total of $100 \mathrm{ml}$ of spore suspension or irrigation water or $50 \mathrm{ml}$ of irrigation runoff, unless stated otherwise (Table 2). Periods required for individual membranes filtering irrigation water and runoff were timed and compared using the analysis of variance (ANOVA) procedure (SAS Institute, Cary, NC).

Spreading membrane washings. Spreading membrane washings (SW) is one of two primary plating methods in filter-based isolation. We used a protocol developed by McDonald et al. (18) with some modifications (Fig. 1). Briefly, each membrane was

TABLE 1. Specifications of the membrane filters evaluated in this study

\begin{tabular}{|c|c|c|c|c|c|c|c|}
\hline \multirow[b]{2}{*}{ Membrane $^{\mathrm{x}}$} & \multirow[b]{2}{*}{ Pore size $(\mu \mathrm{m})$} & \multirow[b]{2}{*}{ Material } & \multirow[b]{2}{*}{ Thickness $(\mu \mathrm{m})$} & \multirow[b]{2}{*}{ Special characters } & \multirow[b]{2}{*}{ Manufacturer } & \multicolumn{2}{|c|}{ Bacterial rating $^{y}$} \\
\hline & & & & & & SW & DIM \\
\hline Isopore5 & 5.0 & Polycarbonate & 9-11 & Smooth surface & Millipore & + & ++ \\
\hline Millipore5 & 5.0 & Mixed cellulose ester & $105-180$ & $\mathrm{ND}^{\mathrm{z}}$ & Millipore & + & ++ \\
\hline Durapore5 & 5.0 & Polyvinylidene fluoride & 125 & Low protein binding & Millipore & + & ++ \\
\hline Osmonics5 & 5.0 & Nylon & 110 & ND & Osmonics & + & +++ \\
\hline Nucleopore3 & 3.0 & Polycarbonate & $6-11$ & Smooth surface & Whatman & + & ++ \\
\hline Nucleopore 0.4 & 0.4 & Polycarbonate & $6-11$ & Smooth surface & Whatman & + & + \\
\hline Millipore0.45 & 0.45 & Mixed cellulose ester & $105-180$ & ND & Millipore & + & ++++ \\
\hline Fisher0.45 & 0.45 & Nitrocellulose & ND & For coliform counts & Millipore & + & ++++ \\
\hline Whatman 0.45 & 0.45 & Nylon & 88 & High protein binding & Whatman & + & +++ \\
\hline
\end{tabular}

${ }^{\mathrm{x}}$ Listed by brand and pore size.

y Two plating methods: $\mathrm{SW}=$ spreading membrane washings, and DIM = directly inverting membranes on the surface of a selective medium in petri dishes.

Visual rating: $+=1$ to 10 colonies, $++=11$ to 100 colonies, $+++=101$ to 500 colonies, and $++++=>500$ colonies per petri dish.

${ }^{\mathrm{z}} \mathrm{ND}=$ not determined.

TABLE 2. Sources and volumes of water that was filtered for different plating methods and the units of pathogen recovery used in the present study

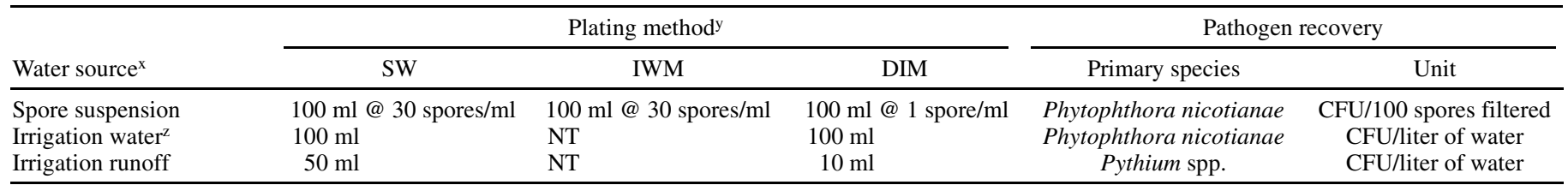

${ }^{\mathrm{x}}$ Spore suspensions of Phytophthora nicotianae were prepared freshly for individual tests of membranes. Irrigation water and irrigation runoff water were collected from a commercial nursery in eastern Virginia.

${ }^{y} \mathrm{SW}=$ spreading membrane washing, IWM = inverting washed membrane, and DIM = directly inverting membrane without washing. NT = not tested.

${ }^{\mathrm{z}}$ Irrigation water was supplemented with Phytophthora nicotianae at 30 spores per $\mathrm{ml}$ for the SW plating method and 1 spore per ml for the DIM method prior to filtration. 
placed in a test tube containing $6 \mathrm{ml}$ of $0.09 \%$ sterile water agar immediately after filtering a water sample. Spores trapped on the membrane were resuspended in water agar by vortexing the test tube for $30 \mathrm{~s}$. An aliquot of $100 \mu \mathrm{l}$ of the membrane washing was then spread onto a $9-\mathrm{cm}$ petri dish containing $20 \mathrm{ml}$ of PARP-V8 agar, pythiaceous-selective medium (10). Inoculated dishes were incubated at $23^{\circ} \mathrm{C}$ in the dark. These dishes were examined daily for mycelial growth with a dissecting microscope. Developing colonies suspected of pythiaceous species were counted daily in each dish until no new colonies were found. Identity of counted colonies was confirmed by examining a portion (25\%) for morphological traits based on keys for identification of Phytophthora $(8,30)$ and Pythium $(4,35)$ in the preliminary tests. Most colonies recovered from irrigation runoff samples were identified as Pythium spp., whereas the majority of colonies recovered from the other sources of water samples were Phytophthora nicotianae (Table 2). For spore suspension samples, the number of CFU per 100 zoospores filtered, which was converted from the number of counted colonies in individual dishes, will be referred to as the recovery of Phytophthora in this study. For both irrigation water and runoff samples, the numbers of CFU per liter of water, converted from the numbers of CFU recovered in individual dishes, will be referred to as the recovery of pythiaceous species (Table 2). The recovery data were standardized, by dividing by the maximal recovery in a test, to facilitate comparison. The standardized recoveries (relative recoveries) were pooled after homogeneity tests. Membrane comparisons were then conducted within the same water sample sources after a square-root transformation using the ANOVA procedure. Bacterial contamination was also visually rated. The rating scale included + for 1 to 10 colonies, ++ for 11 to 100 colonies, +++ for 101 to 500 colonies, and ++++ for $>500$ colonies.

Inverting washed membranes. Membranes that filtered $100 \mathrm{ml}$ of spore suspension of Phytophthora nicotianae were washed in $6 \mathrm{ml}$ of $0.09 \%$ water agar, as described previously, and inverted on the surface of PARP-V8 agar in petri dishes (Fig. 1). The membranes were discarded after 1-day incubation in the dark at $23^{\circ} \mathrm{C}$; subsequently, bacterial colonies or smears were noted and removed from membrane-placing area with a sterile cell scraper. Phytophthora colonies were counted. The number of CFU recovered from washed membranes was calculated, analyzed as described above without standardization and transformation, and compared with that of CFU recovered through the SW plating method.
Directly inverting membranes. Directly inverting membranes (DIM) (Fig. 1) is another commonly used plating method in filterbased isolation. We also used this method to compare the membranes for recovery of pythiaceous species from spore suspension, irrigation water, and irrigation runoff (Table 2). Each membrane filtered $100 \mathrm{ml}$ of spore suspension at 1 spore per $\mathrm{ml}$ of Phytophthora nicotianae, $100 \mathrm{ml}$ of irrigation water supplemented with 1 spore per $\mathrm{ml}$, or $10 \mathrm{ml}$ of irrigation runoff. The membrane was then placed face down on the surface of PARP-V8 agar in a 9-cm petri dish. Membranes were discarded after 1-day incubation in the dark at $23^{\circ} \mathrm{C}$. Subsequently, bacterial colonies or smears were noted and removed from the dishes. Colonies of pythiaceous species in membrane placement area were counted daily until they merged. The recovery data were calculated, standardized, and analyzed as previously described.

Spreading filtrates. Spreading filtrates (Fig. 1) was used to determine if pythiaceous propagules could escape the membranes during filtration. Irrigation water supplemented with Phytophthora nicotianae at 30 spores per $\mathrm{ml}$ was filtered as described previously. An aliquot of $300 \mathrm{ml}$ of filtrate that passed through one of nine membranes was centrifuged with a Sorvall (RC 5C Plus; Kendro Laboratory Products, Newtown, CT) at $10,000 \times g$ for $10 \mathrm{~min}$. Each pellet was resuspended in $3 \mathrm{ml}$ of sterile distilled water (SDW), and $200 \mu \mathrm{l}$ of resulting suspension was spread in one of three $9-\mathrm{cm}$ petri dishes containing PARP-V8 agar. This

TABLE 3. Time in seconds required for filtering $100 \mathrm{ml}$ of irrigation water or $50 \mathrm{ml}$ of irrigation runoff collected from a commercial nursery in eastern Virginia $^{z}$

\begin{tabular}{lcc}
\hline Filter & Irrigation water & Irrigation runoff \\
\hline Isopore5 & $306 \mathrm{~b}$ & $657 \mathrm{~b}$ \\
Millipore5 & $7 \mathrm{~g}$ & $6 \mathrm{e}$ \\
Durapore5 & $10 \mathrm{fg}$ & $8 \mathrm{e}$ \\
Osmonics5 & $9 \mathrm{fg}$ & $9 \mathrm{e}$ \\
Nucleopore3 & $281 \mathrm{c}$ & $591 \mathrm{~b}$ \\
Nucleopore0.4 & $654 \mathrm{a}$ & $809 \mathrm{a}$ \\
Millipore0.45 & $90 \mathrm{e}$ & $101 \mathrm{~d}$ \\
Fisher0.45 & $34 \mathrm{f}$ & $74 \mathrm{de}$ \\
Whatman0.45 & $207 \mathrm{~d}$ & $189 \mathrm{c}$ \\
\hline
\end{tabular}

${ }^{\mathrm{z}}$ Two membranes of the same type were used due to blockage of the first membranes after filtering runoff for 9 min and irrigation water for $5 \mathrm{~min}$. Values within the same column followed by the same letter are not significantly different according to the LSD test at $P<0.05$.

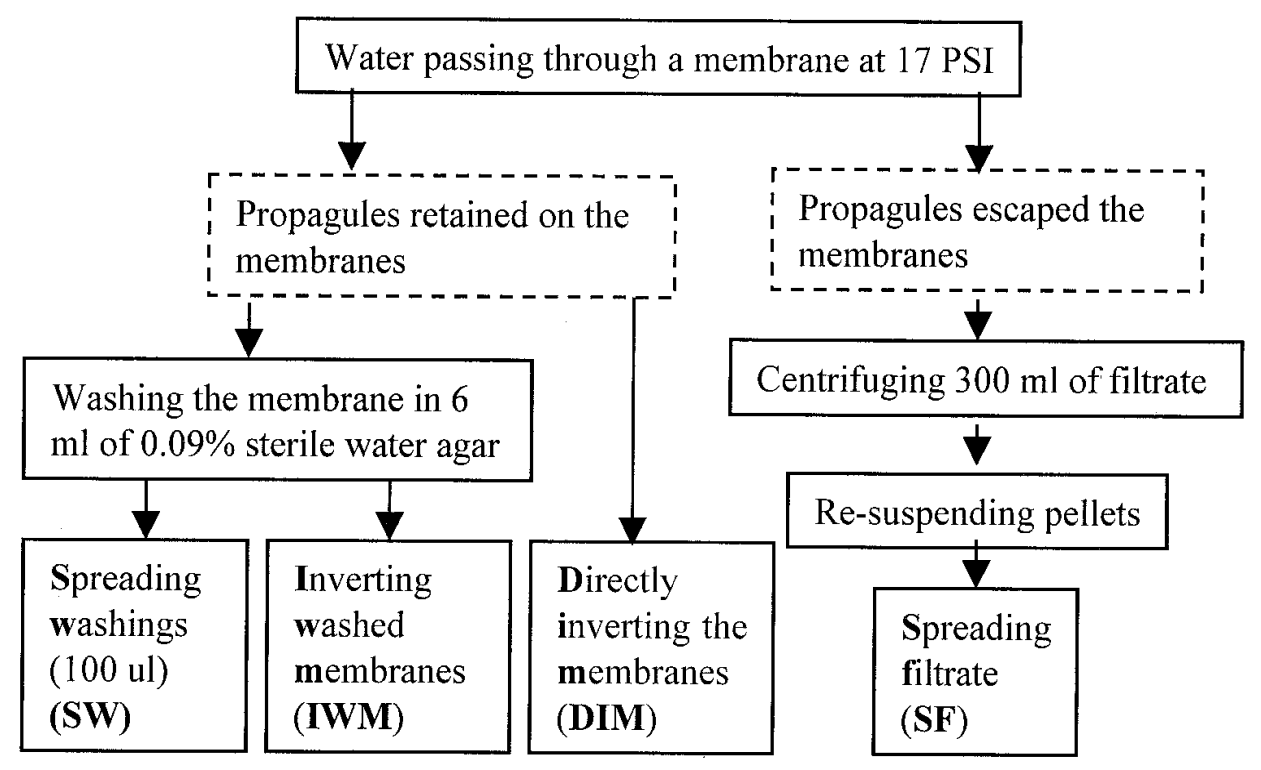

Fig. 1. Schematic diagram of filtration and three plating methods used in the study comparing efficiency of nine membrane filters for recovering pythiaceous species from irrigation water. 
experiment was repeated using a slightly improved procedure. Pellets from $300 \mathrm{ml}$ of centrifuged filtrate were resuspended in $1 \mathrm{ml}$ of SDW and the entire amount of each resulting suspension was spread in a petri dish with the same medium. Subsequently, CFU of pythiaceous species in individual dishes were counted and converted to CFU per liter of filtrate for each membrane.

\section{RESULTS}

Membranes and filtration. Polycarbonate membranes required significantly more time to filter both irrigation water and runoff samples than the other membranes (Table 3). The first polycarbonate membranes were obstructed before $50 \mathrm{ml}$ of irrigation runoff was passed through and a second membrane was needed for completion of the filtration. The period required for filtering $50 \mathrm{ml}$ of irrigation runoff with two membranes (of the same type) spanned 10 to 13 min (Table 3 ). A second membrane was also needed for two of three polycarbonate membranes (Isopore5 and Nucleopore 0.4) to filter $100 \mathrm{ml}$ of irrigation water. The time needed to filter irrigation water samples ranged from 5 to $11 \mathrm{~min}$ (Table 3).

Filtering time decreased with increased pore size of membranes of the same types and manufactured by the same companies (Table 3). Millipore5, Durapore5, and Osmonics5 needed only $10 \mathrm{~s}$ or less to filter irrigation water or runoff samples, whereas the other membranes required 0.5 to $13.4 \mathrm{~min}$ for the same volume water samples. Interestingly, a 5 - $\mu \mathrm{m}$ polycarbonate membrane (Isopore5) manufactured by Millipore needed more time than a $3-\mu \mathrm{m}$ membrane of the same type made by Whatman to

TABLE 4. Comparison of membranes for relative recovery of pythiaceous species from spore suspension, irrigation water, or irrigation runoff collected from a commercial nursery in Virginia

\begin{tabular}{llccc}
\hline Method & Statistics & $\begin{array}{c}\text { Spore } \\
\text { suspension }\end{array}$ & $\begin{array}{c}\text { Irrigation } \\
\text { water }\end{array}$ & $\begin{array}{c}\text { Irrigation } \\
\text { runoff }\end{array}$ \\
\hline SW & $P$ & 0.0248 & 0.0058 & 0.5279 \\
& Top two membranes & Osmonics5 & Nucleopore0.4 & $\mathrm{NS}^{\mathrm{z}}$ \\
& & Durapore5 & Durapore5 & $\mathrm{NS}$ \\
\multirow{2}{*}{ DIM } & $P$ & 0.0022 & $<0.0001$ & 0.0591 \\
& Top two membranes & Millipore5 & Durapore5 & Millipore5 \\
& & Durapore5 & Millipore5 & Durapore5 \\
\hline
\end{tabular}

x Plating methods: $\mathrm{SW}=$ spreading membrane washings and DIM $=$ directly inverting membranes on the surface of a selective medium.

y Membrane names listed as in Table 1.

${ }^{\mathrm{z}}$ Not significantly different. filter both irrigation water and runoff samples (Table 3). Membranes of the polycarbonate type or $0.45-\mu \mathrm{m}$ pore size required more time to filter through $50 \mathrm{ml}$ of irrigation runoff than that required for $100 \mathrm{ml}$ of irrigation water, except for Whatman 0.45 (Table 3).

SW plating method. Significantly different recoveries of pythiaceous species were observed among membranes evaluated with spore suspensions and irrigation water but not with the irrigation runoff samples (Table 4; Fig. 2). The top two membranes were Osmonics5 and Durapore5 for spore suspension samples and Nucleopore0.4 and Durapore5 for irrigation water samples (Fig. 2; Table 4). Durapore5 was the only membrane that performed well for both spore suspensions and irrigation water samples, whereas Osmonics5 and Nucleopore0.4 had varied recoveries between the repeat tests and water samples (Fig. 2). Nucleopore3 and Nucleopore 0.4 had the lowest recoveries of Phytophthora from spore suspensions, whereas Millipore5 and Whatman0.45 had the lowest recoveries from irrigation water samples (Fig. 2). Only a few bacterial colonies were observed in isolation petri dishes.

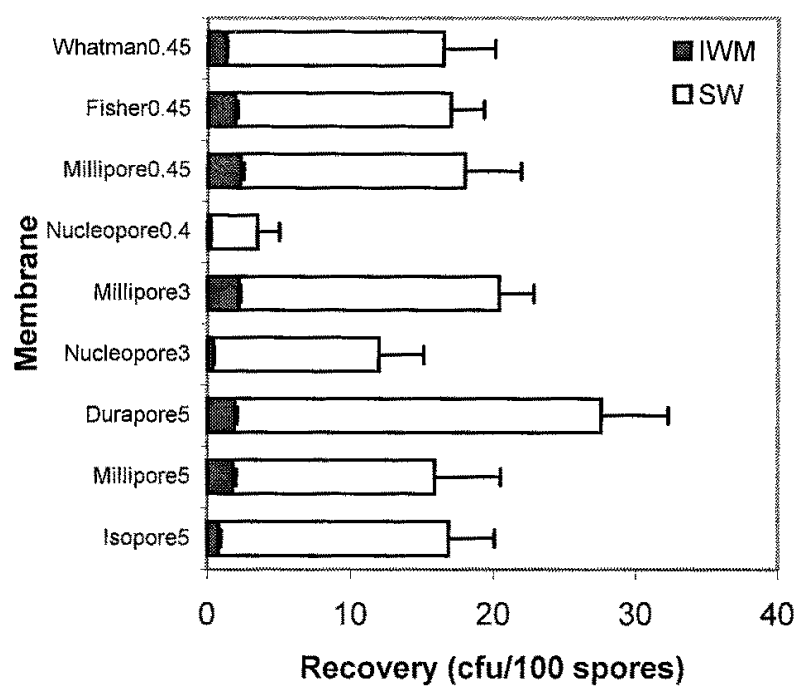

Fig. 3. Recovery of Phytophthora nicotianae per 100 spores filtered when washed membranes were inverted over (IWM), and membrane washings were spread (SW) onto the surface of PARP-V8 agar in 9-cm petri dishes. Each bar represents the mean recovery of six replicated membranes in two

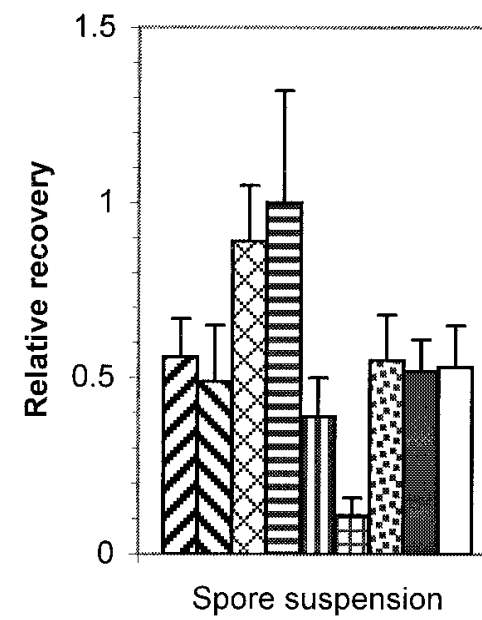

Spore suspension

\author{
Each bar represer
repeated tests.
}


Inverting washed membranes. Recoveries of Phytophthora from washed membranes ranged from 0.1 to $2.9 \mathrm{CFU}$ per 100 spores filtered on the first occasion and 0 to $3.0 \mathrm{CFU}$ per 100 spores filtered on the second occasion. Significantly different recoveries were found among the membranes $(P<0.0001)$. Three polycarbonate membranes had the least recoveries, whereas Millipore0.45, Millipore3, Durapore5, and Fisher0.45 had the greatest recoveries (Fig. 3). The number of CFU recovered through inverting washed membranes (IWM) was proportional to that of CFU recovered through the SW plating method (Fig. 4).

DIM. No differences were observed in recovery of pythiaceous species between the tests within the same water sample sources (spore suspensions, irrigation water, or runoff). However, there were significant differences in the recovery of pythiaceous species from spore suspension $(P=0.0022)$, irrigation water $(P<0.0001)$, and runoff $(P=0.0591)$ among the membranes evaluated in this study (Fig. 5; Table 4). Overall, Millipore5 and Durapore5 had the greatest recoveries, whereas Osmonics5 had the lowest recoveries, for all water samples (Fig. 5).

Spreading filtrates. Pythiaceous species were recovered from irrigation water filtrates of two membranes on 3 July, with Isopore5 at 267.0 CFU/liter and Nucleopore3 at 33.0 CFU/liter.

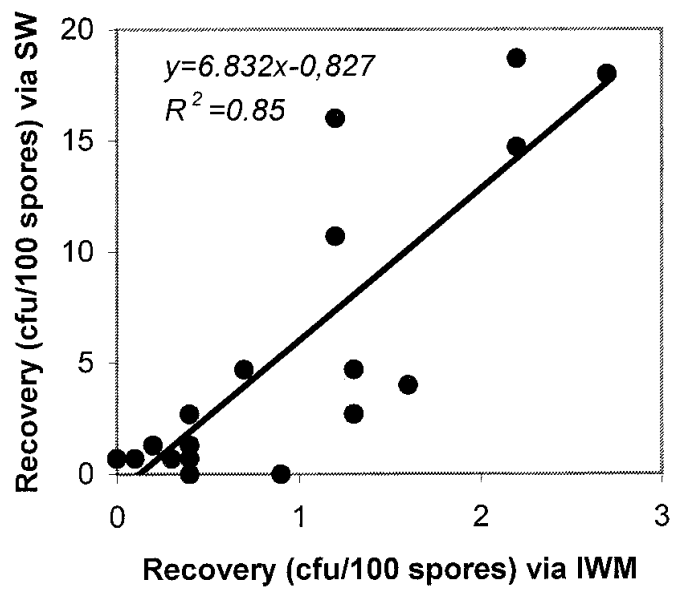

Fig. 4. Relationship between two plating methods for recoveries of Phytophthora spp. from spore suspension. The two methods were inverting washed membranes (IWM) and spreading membrane washings (SW) on PARPV8 agar.
Pythiaceous species were recovered from filtrates of more membranes on 16 July, with Durapore5 at 16.7 CFU/liter, Whatman0.45 at 5.7 CFU/liter, Nucleopore0.4 at $4.3 \mathrm{CFU} / \mathrm{liter}$, Isopore5 at $60.0 \mathrm{CFU} / \mathrm{liter}$, and Nucleopore3 at $62.3 \mathrm{CFU} / \mathrm{liter}$ (Table 5). Pythiaceous species were not recovered from filtrates of any other membranes in either of the two tests (Table 5).

\section{DISCUSSION}

This study provides an evaluation of nine hydrophilic membranes for recovering pythiaceous propagules from three sources of water samples using different plating methods. Durapore5 and Millipore5 consistently outperformed the other membranes evaluated by the DIM plating method for all water samples in this study (Fig. 5). Durapore5 was also the only membrane that outperformed other membranes tested with the SW plating method for both spore suspension and irrigation water samples (Fig. 2). In addition, Durapore5 was one of the three most time-efficient membranes (Table 3). These findings have significant implication on the development and implementation of integrated management strategies for waterborne pathogens and the plant diseases they cause. Sensitivity of isolation methods is critical to pathogen

TABLE 5. Recovery of pythiaceous species from filtrate of irrigation water that passed through membranes included in the present study ${ }^{z}$

\begin{tabular}{lcc}
\hline & \multicolumn{2}{c}{ Colony-forming unit/liter of water } \\
\cline { 2 - 3 } Membrane & $07 / 03$ & $07 / 16$ \\
\hline Isopore5 & 267.0 & 60.0 \\
Millipore5 & 0 & 0 \\
Durapore5 & 0 & 16.7 \\
Osmonics5 & 0 & 0 \\
Nucleopore3 & 33.0 & 62.3 \\
Nucleopore0.4 & 0 & 4.3 \\
Millipore0.45 & 0 & 0 \\
Fisher0.45 & 0 & 0 \\
Whatman0.45 & 0 & 5.7
\end{tabular}

${ }^{\mathrm{z}}$ Irrigation water was collected from a commercial nursery in eastern Virginia on 3 and 16 July 2001. Both samples were supplemented with 30 spores per $\mathrm{ml}$ of Phytophthora nicotianae prior to filtration. Then $300 \mathrm{ml}$ of filtrate that passed through one of the nine membranes was centrifuged at $10,000 \times g$ for $10 \mathrm{~min}$. For the first sample (07/03), the pellet was resuspended in $3 \mathrm{ml}$ of sterile distilled water (SDW) and $200 \mu \mathrm{l}$ of resulting suspension was spread in one of three petri dishes containing PARP-V8 agar. For the second sample (7/16), the pellet was resuspended in $1 \mathrm{ml}$ of SDW and the entire resulting suspension was spread in one petri dish.

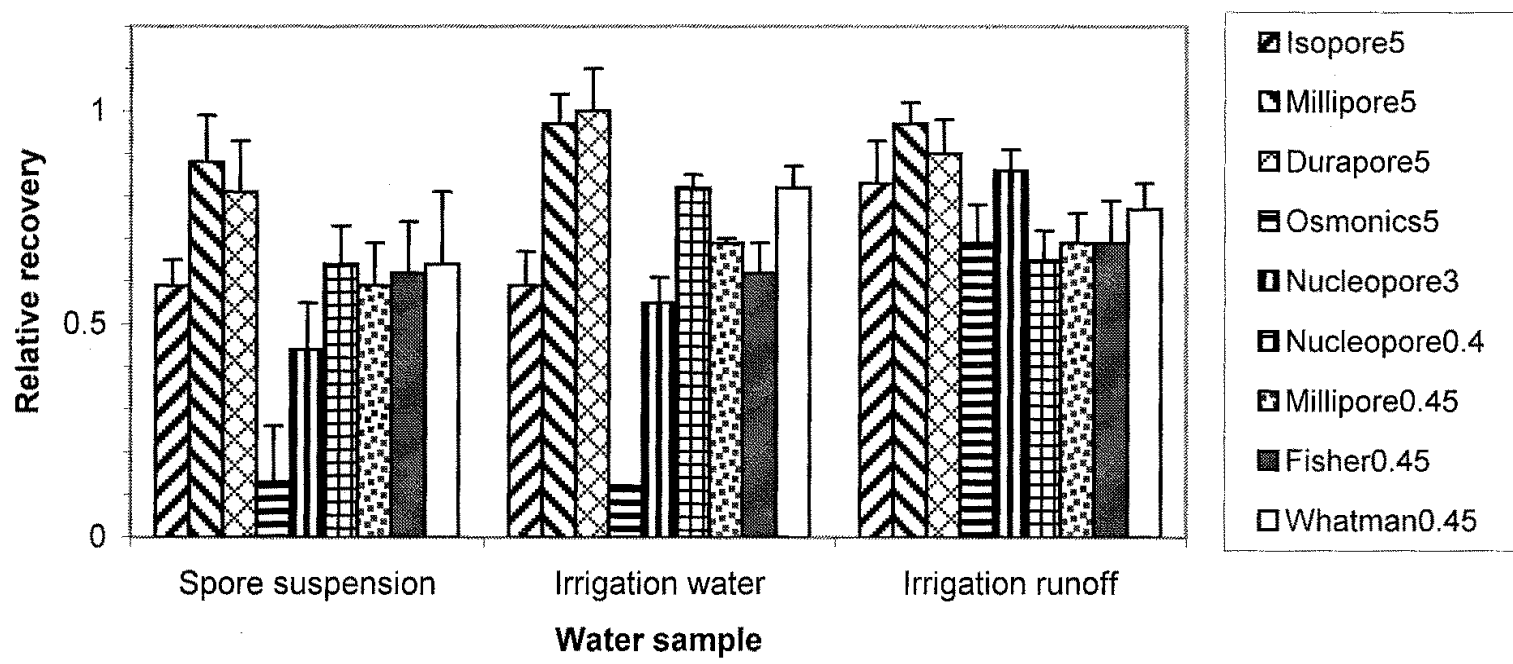

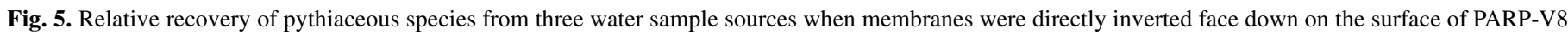

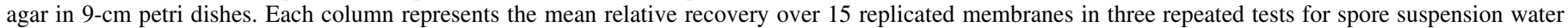
samples and six membranes in two repeated tests for both irrigation water and irrigation runoff samples. Line bars denote standard errors of recovery. 
characterization and diagnosis of water samples when the population of a target species is small or its threshold for crops is extremely low, such as Phytophthora nicotianae on annual vinca (13). Use of Durapore5 not only increases the sensitivity of filterbased isolation, but also saves filtering time. The results of this study also allow for data comparison across locations at regional and national levels.

The differences in the performance of various membranes evaluated were reduced for irrigation runoff when compared with those for irrigation water (Table 4; Figs. 2 and 5). The reduced performance of highly efficient membranes may have been due partly to rapid blockage of filter channels. These results imply that the volume of water filtered is a significant factor affecting pathogen recovery. An appropriate volume of water to be filtered is an amount that can pass through a membrane without hindrance.

DIM plating method produced more consistent data than SW in our study (Figs. 2 and 5). Use of the DIM plating method also saves extra steps required for the SW method, such as resuspending, pipetting, and spreading. However, the DIM method also has disadvantages. For example, growing colonies are difficult to count even with a dissecting microscope and harder to purify because they are concentrated in the membrane placement area. Additional research is needed before any conclusive recommendations can be made on the selection of plating methods. In addition, because the number of CFU recovered through IWM was consistently proportional to that of $\mathrm{CFU}$ recovered through the SW plating method, the IWM plating method could be an alternative to the SW and the DIM for quantifying pythiaceous species in aquatic systems.

To our knowledge, this research is the first to examine pythiaceous species that pass through membranes of $5 \mu \mathrm{m}$ or smaller pore sizes. It was unexpected that these species were recovered from filtrates of several membranes including two $5-\mu \mathrm{m}$ membranes (Isopore5 and Durapore5), one 3- $\mu \mathrm{m}$ membrane (Nucleopore3), and two membranes of pore size less than $1 \mu \mathrm{m}$ (Nucleopore0.4 and Whatman0.45) (Table 5). It was generally considered that $5-\mu \mathrm{m}$ membranes retain all zoospores of pythiaceous species $(25,34)$. Some early investigations even used 8- and $20-\mu \mathrm{m}$ membranes to separate zoospores from sporangia, chlamydospores, and oospores, and to estimate the ratio of zoospores to other types of propagules in irrigation water. The fact that pythiaceous species passed through $0.4-$ and $0.45-\mu \mathrm{m}$ membranes implies that the numbers of zoospores in irrigation water may have been underestimated compared with other types of propagules in these studies $(25,34)$. How zoospores passed through 0.4to 5 - $\mu \mathrm{m}$ membranes is unclear. Swimming zoospores do not have cell walls and spore size is reduced when they are encysted (8). These characteristics may have allowed their passage through the membranes under high vacuum pressure. These data suggest that vacuum pump pressure and filtering period may have an effect on the recovery of pythiaceous species in aquatic systems. Further investigations are warranted to optimize and standardize the pump pressure and filtering period in filter-based isolation. Nevertheless, it is important to determine if propagules of a target pathogen can pass through a membrane before processing any water samples. The number of zoospores that could pass through the membrane should be taken into account when pathogen population is being estimated and quantitative diagnoses are being made of irrigation water samples.

Three polycarbonate membranes included in this study are thin and smooth with a glass-like surface and are ready to examine microscopically for developing colonies. It is still not clear why longer periods of time are needed for these three membranes to filter an irrigation water or runoff sample than those for the other membranes evaluated in this investigation. Washed polycarbonate membranes had lower recoveries, whereas the other membranes had higher recoveries of pythiaceous species (Fig. 3). These results reveal that thin polycarbonate membranes retain fewer pro- pagules in the filter channels after washing. On the other hand, they are more prone to passage of propagules. Therefore, determination of an appropriate vacuum pump pressure and volume of water to avoid prolonged filtering for such membranes is of particular importance to pathogen characterization and disease diagnosis.

The Osmonics5 membrane performed consistently well in the SW plating method but poorly in the DIM plating method (Figs. 2 and 5). This may have been due partly to the chemistry of the membrane materials. This type of membrane should be avoided when possible although its inhibitory impact may be reduced or neutralized after trapped spores are washed off the membrane and spread onto the surface of a selective medium.

\section{ACKNOWLEDGMENTS}

This research was supported in part by USDA/Southern Region IPM Special Grants Program, Virginia Agricultural Council, and Virginia Nursery and Landscape Association. We thank T. Banko for critical reading of the manuscript.

\section{LITERATURE CITED}

1. Ali-Shtayeh, M. S., and MacDonald, J. D. 1991. Occurrence of Phytophthora species in irrigation water in the Nablus area (West Bank of Jordan). Phytopathol. Mediterr. 30:143-150.

2. Ali-Shtayeh, M. S., MacDonald, J. D., and Kabashima, J. 1991. A method for using commercial ELISA tests to detect zoospores of Phytophthora and Pythium species in irrigation water. Plant Dis. 75:305311.

3. Brown, L. R., and Ayres, E. D. 1998. The World Watch Reader on Global Environmental Issues. W. W. Norton \& Co., New York.

4. Dick, M. W. 1990. Keys to Pythium. Published by author, Reading, UK.

5. Dukes, P. D., Jenkins, S. F., Jr., and Thompson, S. S., Jr. 1977. Detection and some observations of Phytophthora parasitica var. nicotianae in ponds used for irrigation of tobacco. Tob. Sci. 2:97-100.

6. Easton, G. D., Nagle, M. E., and Bailey, D. L. 1969. A method of estimating Verticillium albo-altram propagules in field soil and irrigation waste water. Phytopathology 59:1171-1172.

7. Ersek, T., Schoelz, J. E., and English, J. T. 1994. PCR-amplification of species-specific DNA sequences can distinguish among Phytophthora species. Appl. Environ. Microbiol. 60:2616-2621.

8. Erwin, D. C., and Ribeiro, O. K. 1996. Phytophthora Diseases Worldwide. The American Phytopathological Society, St. Paul, MN.

9. Faulkner, L. R., and Bolander, W. J. 1970. Agriculturally-polluted irrigation water as a source of plant-parasitic nematode infestation. J. Nematol. 2:368-374.

10. Ferguson, A. J., and Jeffers, S. N. 1999. Detecting multiple species of Phytophthora in container mixes from ornamental crop nurseries. Plant Dis. 83:1129-1136.

11. Gill, D. L. 1970. Pathogenic Pythium from irrigation ponds. Plant Dis. Rep. 54:1077-1079.

12. Haymes, K., Tooley, P., Thomas, C., Williams, V., Connor, J., Bush, J., Hicks, D., Turpin, R., and Scott, D. 2000. The evaluation of commercial diagnostic kits for the detection of Phytophthora species. (Abstr.) Phytopathology 90(suppl.):S34.

13. Hong, C. X., and Epelman, G. 2001. Effect of pathogen concentration and exposure frequency on Phytophthora blight of annual vinca under drip irrigation systems. (Abstr.) Phytopathology 91(suppl.):S40.

14. Kageyama, K., Ohyama, A., and Hyakumachi, M. 1997. Detection of Pythium ultimum using polymerase chain reaction with species-specific primers. Plant Dis. 81:1155-1160.

15. Klotz, L. J., Wong, P. P., and DeWolfe, T. A. 1959. Survey of irrigation water for the presence of Phytophthora spp. pathogenic to citrus. Plant Dis. Rep. 43:830-832.

16. Lee, S. B., White, T. J., and Taylor, J. W. 1993. Detection of Phytophthora species by oligonucleotide hybridization to amplified ribosomal DNA spacers. Phytopathology 83:177-181.

17. Levesque, C. A., Vrain, T. C., and De Boer, S. H. 1994. Development of a species-specific probe for Pythium ultimum using amplified ribosomal DNA. Phytopathology 84:474-478.

18. MacDonald, J. D., Ali-Shtayeh, M. S., Kabashima, J., and Stites, J. 1994. Occurrence of Phytophthora species in recirculated nursery irrigation effluents. Plant Dis. 78:607-611.

19. MacDonald, J. D., Stites, J., and Kabashima, J. 1990. Comparison of serological and culture plate methods for detecting species of Phytoph- 
thora, Pythium, and Rhizoctonia in ornamental plants. Plant Dis. 74:655659.

20. McCracken, J. L., and Jeffers, S. N. 2000. Some factors affecting recovery of Phytophthora spp. from recycled irrigation water. (Abstr.) Phytopathology 90(suppl.):S127.

21. McIntosh, D. L. 1966. The occurrence of Phytophthora spp. in irrigation systems in British Columbia. Can. J. Bot. 44:1591-1596.

22. Neher, D., and Duniway, J. M. 1992. Dispersal of Phytophthora parasitica in tomato fields by furrow irrigation. Plant Dis. 76:582-586.

23. Oudemans, P. V. 1999. Phytophthora species associated with cranberry root rot and surface irrigation water in New Jersey. Plant Dis. 83:251-258.

24. Pettitt, T. R., Finlay, A. R., Scott, M. A., and Davies, E. M. 1998. Development of a system simulating commercial production conditions for assessing the potential spread of Phytophthora cryptogea root rot of hardy nursery stock in recirculating irrigation water. Appl. Biol. 132:6175 .

25. Pittis, J. E., and Colhoun, J. 1984. Isolation and identification of pythiaceous fungi from irrigation water and their pathogenicity to Antirrhinum, tomato, and Chamaecyparis lawsoniana. Phytopathol. Z. 110:301-318.

26. Runia, W. T., Michielson, J. M. G. P., van Kuik, A. J., and van Os, E. A. 1996. Elimination of root infecting pathogens in recirculation water by slow sand filtration. ISOSC Proc. 395:407.

27. Sanogo, S., and Moorman, G. W. 1993. Transmission and control of Pythium aphanidermatum in an ebb-and flow subirrigation system. Plant Dis. 77:287-290.

28. Schuster, M. 1959. Relation of root-knot nematodes and irrigation water to the incidence and dissemination of bacterial wilt of bean. Plant Dis. Rep. 43:27-32.

29. Shokes, F. M., and McCarter, S. M. 1979. Occurrence, dissemination, and survival of plant pathogens in surface irrigation ponds in southern Georgia. Phytopathology 69:510-516.
30. Stamps, D. J., Waterhouse, G. M., Newhook, F. J., and Hall, G. S. 1990. Revised Tabular Key to the Species of Phytophthora. CAB Mycol. Pap. No. 162. Kew, Surrey, England.

31. Stanghellini, M. E., Kim, D. H., Rasmussen, S. L., and Rorabaugh, P. A. 1996. Control of root rot of peppers caused by Phytophthora capsici with a nonionic surfactant. Plant Dis. 80:1113-1116.

32. Thomas, S. B. L., White, J., and Taylor, J. W. 1993. Detection of Phytophthora species by oligonucleotide hybridization to amplified ribosomal DNA spacers. Phytopathology 83:177-181.

33. Thompson, D. L. 1965. Control of bacterial stalk rot of corn by chlorination of water in sprinkler irrigation. Crop Sci. 5:369-370.

34. Thomson, S. V., and Allen, R. M. 1974. Occurrence of Phytophthora species and other potential plant pathogens in recycled irrigation water. Plant Dis. Rep. 58:945-949.

35. van der Plaats-Niterink, A. J. 1981. Monograph of the Genus Pythium. Institute of the Royal Netherlands Academy of Sciences and Letters, Baarn, the Netherlands.

36. van Kuik, A. J. 1992. Spread of Phytophthora cinnamomi Rands in a recycling system. Meded. Fac. Landbouwwet. Univ. Gent. 57:139-143.

37. von Broembsen, S. L. 1984. Distribution of Phytophthora cinnamomi in rivers of the South Western Cape Province. Phytophylactica 16:227-229.

38. von Broembsen, S. L., and Wilson, S. K. 1998. Occurrence of Phytophthora spp. in nursery runoff and recycled irrigation water. (Abstr.) Phytopathology 88(suppl.):S92.

39. Wakeham, A. J., Pettitt, T. R., and White, J. G. 1997. A novel method for detection of viable zoospores of Pythium in irrigation water. Ann. Appl. Biol. 131:427-435.

40. Whiteside, J. O., and Oswalt, T. W. 1973. An unusual brown rot outbreak in a Florida citrus grove following sprinkler irrigation with Phytophthora-infested water. Plant Dis. Rep. 57:391-393.

41. Yuen, G. Y., Craig, M. L., and Avila, F. 1993. Detection of Pythium ultimum with a species-specific monoclonal antibody. Plant Dis. 77:692-698. 